Semmelweis Egyetem, Fogorvostudományi Kar, Parodontológiai Klinika, Budapest, Magyarország* Empresa de Base Tecnológica Internacional de Canarias, S.L. (EBATINCA), Las Palmas de Gran Canaria, Spanyolország** Department of Prevention and Communal Dentistry, Sechenov First State Medical University, Moszkva, Oroszország***

\title{
Virtuális tervezés és volumetrikus kiértékelés egy komplex parodontális defektus regeneratív-rekonstruktív sebészi ellátásában
}

\author{
Egy eset bemutatása
}

\author{
DR. SÓLYOM ELEONÓRA*, DR. PALKOVICS DÁNIEL*, DR. PINTÉR CSABA**, \\ DR. FRANCESCO GUIDO MANGANO***, DR. WINDISCH PÉTER* \\ (DR. SÓLYOM ELEONÓRA és DR. PALKOVICS DÁNIEL megosztott első szerzők)
}

\begin{abstract}
Célkitüzés: Célunk egy parodontális defektus regeneratív-rekonstruktív sebészi ellátásának és a mútétek digitális tervezésének bemutatása hibrid virtuális modell alapján, továbbá a pre- és postoperatív cone-beam computer tomográf (CBCT) felvételek pontos térbeli illesztésével a változások digitális kiértékelése.

Vizsgálati anyag és módszer: Félautomatikus szegmentációs módszer alapján a CBCT-ből előállított, keményszöveti modellt és az intraorális szkennerrel vett digitális mintát identikus anatómiai pontok alapján történő illesztését követően terveztük a sebészi beavatkozásokat. Első lépésben a 26-os fog eltávolításával egybekötött alveolus prezevációt végeztük el az „extraction site development (XSD)” technika alapján. Majd a 24-es és 25-ös fogakat érintő defektus minimálinvazív regeneratív célzatú ellátását végeztük. A preoperatív és postoperatív CBCT felvételek illesztésével és szubtrakciójával volumetrikusan és lineárisan értékeltük ki a beavatkozások eredményét.

Eredmények: Az érintett területen összesen $0,44 \mathrm{~cm}^{3}$ keményszöveti többlet keletkezett. Ezzel együtt megfigyelhető kismértékủ marginális csontrezorpció, melynek mértéke összesen $0,11 \mathrm{~cm}^{3}$. Lineáris mérések alapján 24-es és 25-ös fogak körül kialakult cirkumdentális, horizonto-vertikális defektus átlagosan 53,88 \pm 36,84\%-os keményszöveti telődést mutatott, a kresztális csontszél kismértékủ lebomlása és 1,22 $\pm 0,87$ ínyrecesszió kialakulása mellett.

Konklúzió: Megállapítható, hogy valósághű hibrid modellek segítségével nagy alapossággal tervezhető meg regeneratívrekonstruktív sebészeti beavatkozások lépései. Valamint pre- és postoperatív CBCT felvételek szubtrakciójával megismerhettük a defektus gyógyulásának mechanizmusait.
\end{abstract}

Kulcsszavak: virtuális műtéti tervezés, regeneratív-rekonstruktív parodontális sebészet, CBCT, szegmentáció, 3D radiológiai képrekonstrukció

\section{Bevezetés}

A regeneratív parodontális sebészet két fő irányvonala; (i) újszerủ mútéti eljárások kidolgozása, valamint (ii) parodontális regenerációt elősegítő bioanyagok kifejlesztése. A mútéti beavatkozások fejlődése terén egyre inkább a minimálisan invazív mútéti beavatkozások kerülnek előtérbe $[6,7,14,20,26]$. A kismértékü lebenyképzés előnye a konvencionális parodontális beavatkozásokkal szemben, hogy jobb vérrögstabilitás érhető el, ami fokozza a seb regenerációs potenciálját. [1, 4, 24]. Hátránya azonban, hogy a minimális lebeny-eleváció miatt csökkent a direkt vizuális kontroll mútét közben.

Számos szerző javasolja cone-beam computer tomográfia (CBCT) alkalmazását [8, 12, 27, 28] olyan esetekben, ahol a konvencionális diagnosztikus módszerek (direkt klinikai mérések és intraorális röntgenfelvételek) nem nyújtanak elég információt a defektusok morfológiájáról. A fent említett közleményekben a defektusok vizsgálata a CBCT kétdimenziós (2D) sagittális, koronális és axiális orientációjú szeletein történt. Radiológiai képrekonstrukciós eljárásokkal (szegmentáció) azonban virtuális 3D-s modellek állíthatók elő a CBCT adathalmazból, melyeken feltérképezhető a valós 3D-s defektusmorfológia [13, 18, 21, 23].

Ezen cikkek többsége ún. „thresholding”, azaz határérték alapú szegmentációs algoritmust alkalmaz [13, 18, 23]. Hátránya, hogy az algoritmus nem tesz különbséget anatómiai struktúrák és fém műtermékek között, ezért a modellek kevés diagnosztikus információval bírnak. 2020-ban publikált közleményben csoportunk egy félautomatikus szegmentációs módszert dolgozott ki fogak és alveoláris csont rekonstrukciójára, mely segítségével valósághű virtuális modellek hozhatók létre parodontális defektusok 3D-s vizualizációja és sebészeti beavatkozások tervezése céljából [21]. Azonban 
csak a keményszövetek 3D-s megjelenítése történt, holott pontosabb tervezéshez és virtuális mútéti szimulációhoz szükséges a lágyrészeket is tartalmazó virtuális modell létrehozása.

Esetbemutatásunk célja egy parodontális defektus regeneratív-rekonstruktív sebészi ellátásának és a mútétek digitális tervezésének bemutatása - fogakat, alveoláris csontot és lágyrészeket egyaránt tartalmazó - hibrid digitális modell alapján. Célunk továbbá a pre- és postoperatív CBCT felvételek pontos térbeli illesztésével, digitálisan kiértékelni a lineáris és volumetrikus változásokat.

\section{Vizsgálati anyag és módszer}

\section{Páciens-szelekció}

Az esetismertetésben szereplő páciens a Semmelweis Egyetem Parodontológiai Klinikáján parodontális kezelés alatt álló, jó általános egészségügyi állapottal rendelkező, nem dohányzó, 53 éves férfi. A vizsgálat a 2008-as helsinki orvosetikai iránymutatásoknak megfelelően a páciens alapos tájékoztatásával és írásos beleegyezésével zajlott. A páciensnél III. stádiumú, B osztályú parodontitis [11, 22] volt diagnosztizálható. A bemutatott esetben a bal felső premoláris- és a moláris fogakat érintő nagy kiterjedésű, komplex horizontovertikális defektus regeneratív-rekonstruktív sebészi kezelését végeztük (1. kép).

\section{Digitális információszerzés}

A keményszövetek leképezése és modellalkotás céljából az oki parodontális kezelést követően, valamint 9 hónappal a mútéti beavatkozások után készült CBCT felvétel (Viso ${ }^{\mathrm{TM}}$ G7, Planmeca, Helsinki, Finnország). Közepes térfogatú (Field-of-view (FOV): $140 \times 100$ mm) felvételek $150 \mu \mathrm{m}$-es voxel mérettel, $100 \mathrm{kV}$ feszültséggel és $12 \mathrm{~mA}$ áramerősséggel készültek [15].

A lágyrészek digitális modellezése és a hibrid virtuális modellalkotás céljából intraorális optikai szkenner segítségével (TRIOS $3^{\mathrm{TM}}$, 3Shape, Koppenhága, Dánia) digitális lenyomatot készítettünk a pontos klinikai szituációról mind a kiindulási állapotban, mind pedig beavatkozások után 9 hónappal a kontroll vizsgálat során.

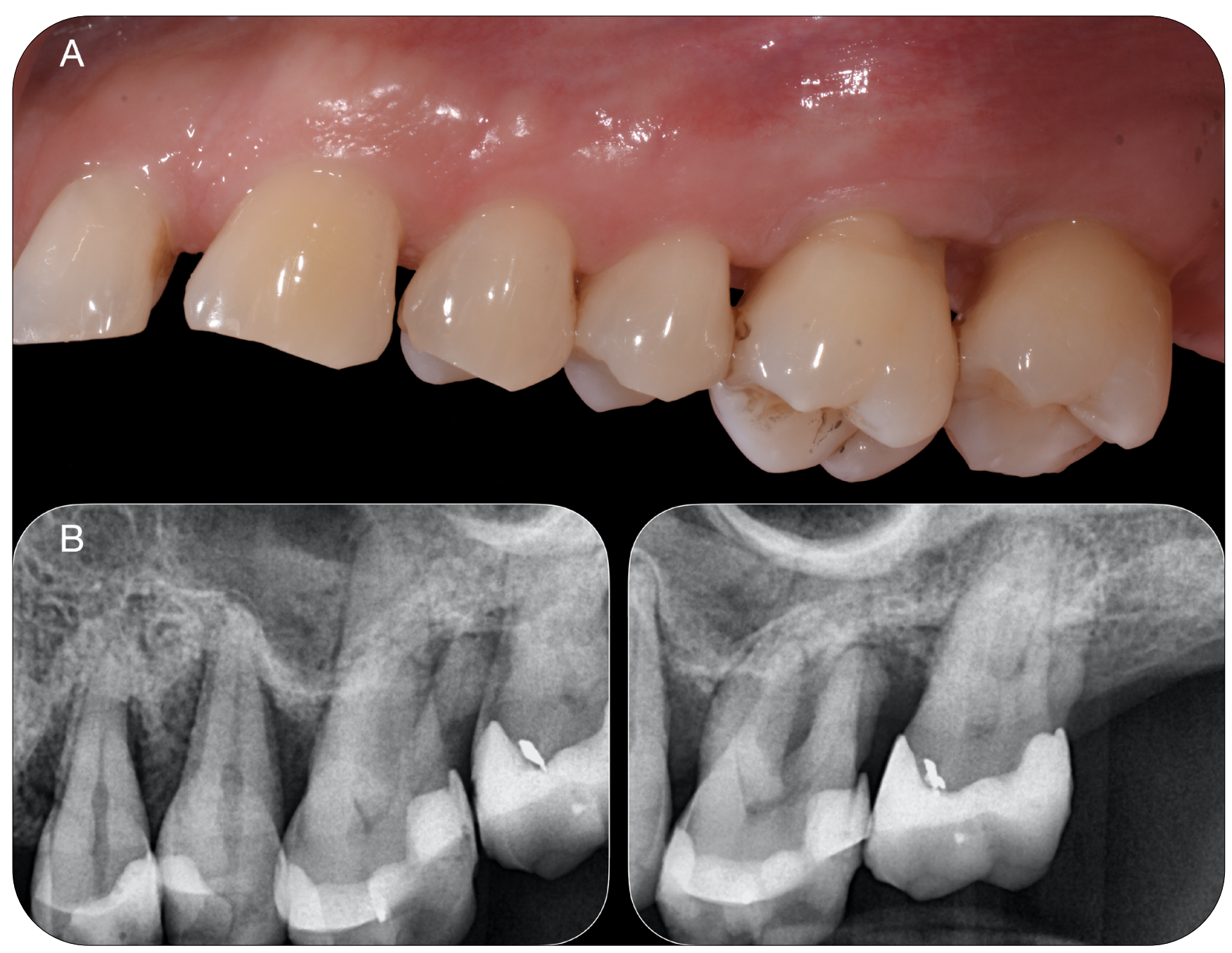

1. kép: Kiindulás állapot:

$A$ : Klinikai szituáció $B$ : Parodontális státusz felvétel 


\section{Virtuális hibrid modellalkotás}

Szegmentáció során CBCT képeken az alveoláris csontot és a fogakat három dimenzióban rekonstruáltuk az egyszerübb diagnosztika céljából. DICOM (Digital Imaging and Communications in Medicine) adatokat egy ingyenesen elérhető (open source) radiológiai képfeldolgozó szoftver (3D Slicer) [10] adatbázisába importáltuk. Csoportunk által kidolgozott félautomatikus szegmentálási módszer alapján [21] félautomata és manuális eszközökkel az alveoláris csontnak és fogaknak megfelelően külön érdeklődési területet (region of interest: ROI) hozunk létre. A 2D-s képeken kijelölt ROI alapján a program automatikusan egy 3D poligon modellt generál (2. kép).

Ezt követően az intraorális szkennerrel vett digitális mintát a CBCT adathalmazra identikus anatómiai pontok alapján illesztettük. 3D Slicer Image Guided Therapy (IGT) bővítésében található „Fiducial Registration Wizard" modult alkalmazva, a fogak incizális élén, csücskein a zománc-cement határon midbukkálisan jelöltük ki az identikus pontokat az intraorális szkennerrel vett digitális modellen és a CBCT alapján rekonstruált 3D-s modellen. Az illesztés pontossága a CBCT 2D-s képein ellenőrizhető, amennyiben nem megfelelő az illesztés, több pont kijelölésével pontosítható az eredmény (3. kép).

A szegmentációval előállított, fogakat és alveoláris csontot tartalmazó poligon modellt és a ráillesztett, lágyrészeket tartalmazó digitális lenyomatot, .stl file-ként további kidolgozás céljából egy ingyenesen elérhető 3D pro- totípus-tervező szoftverbe importáljuk (Meshmixer ${ }^{\circledR}$, Autodesk, San Rafael, Kalifornia, USA). A metódust a kiindulási és kontroll CBCT felvételek esetében is elvégeztük (4. kép).

\section{Mútéti kezelés}

\section{Első beavatkozás - Alveolus prezerváció}

Bal felső, első moláris fog eltávolításával egybekötött alveolus prezervációt a korábban leírt „extraction site development (XSD)" technika alapján végeztük (5. kép). Helyi érzéstelenítésben, a 26-os fog eltávolítását követően a 25-ös és 26-os fogak között, bukkálisan ejtett vertikális segédmetszésből kétrétegű tunnel lebenyt preparáltunk. A bukkális csontfelszínre hosszú felszívódási idejú membránt (Soft Cortical Lamina ${ }^{\circledR}$, Tecnoss, Torino, Olaszország) rögzítettünk titánszegek segítségével a bukkális csontfal helyreállítása céljából. Szupraperioszteálisan xenogén eredetű kollagén mátrixot (Mucoderm ${ }^{\circledR}$, Botiss, Zossen, Németország) füztünk be, az ideális lágyrészkontúr helyreállításához. $A z$ alveolus üregébe felszívódó, laza szerkezetű kollagén szivacsot (Lyostypt ${ }^{\circledR}, \mathrm{B}$. Braun, Melsungen, Németország) helyeztünk a megnövelt vérrög stabilizációja céljából. Az alveolust keresztezett, külső, horizontális matracöltéssel, a vertikális segédmetszéseket horizontális matracöltésekkel varrtuk össze (Dafilon, B Braun ${ }^{\circledR}$, Melsungen, Németország). Varratszedésre a mútét után 14 nappal került sor [19].

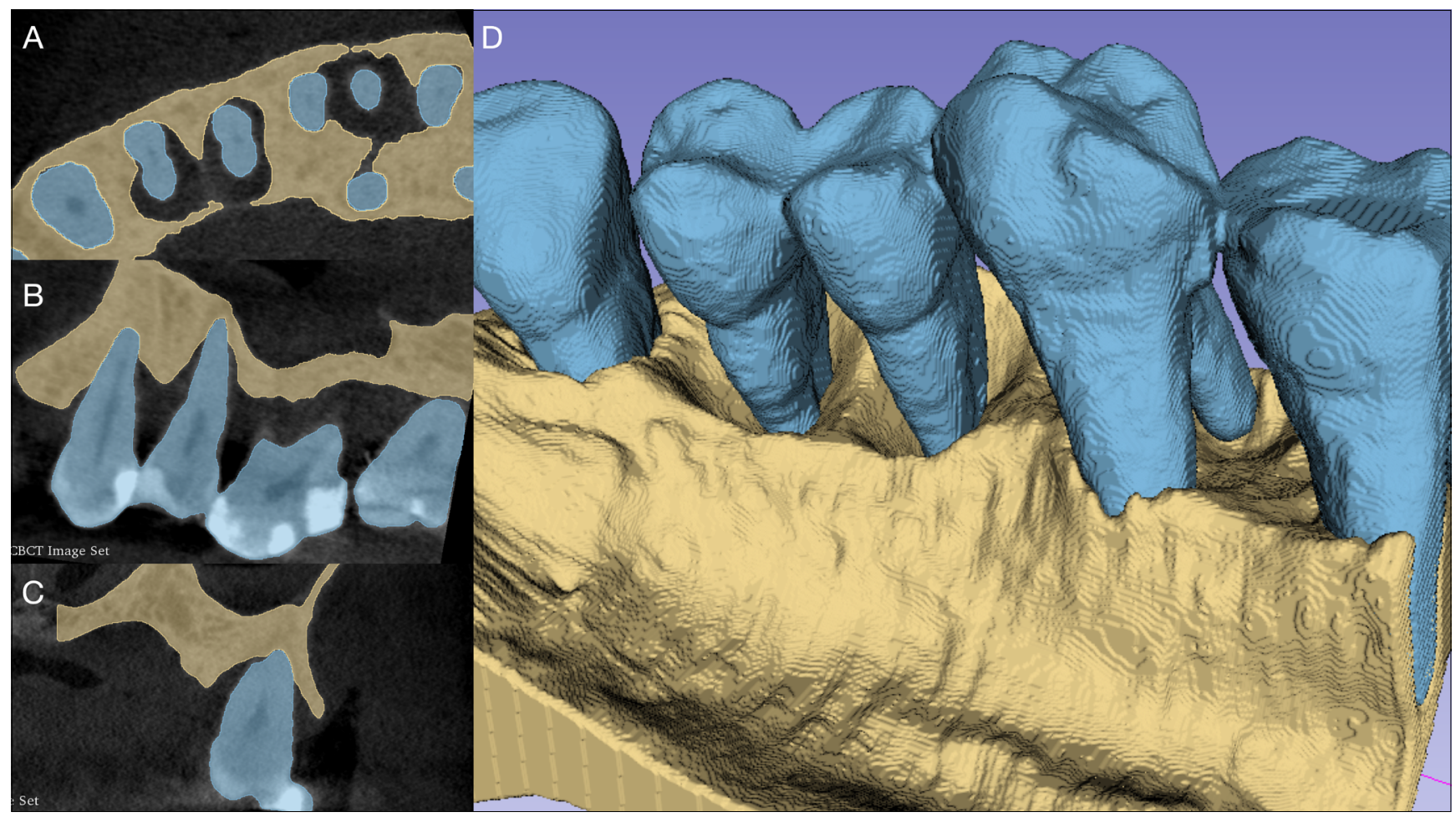

2. kép: Radiológiai képrekonstrukció:

$A$ : Érdeklődés területei (Regions of interest: ROI) a 2D-s axiális képen

$B$ : Érdeklődés területei (Regions of interest: ROI) a 2D-s sagittális képen

C: Érdeklődés területei (Regions of interest: ROI) a 2D-s koronális képen $D$ : 3D képrekonstrukcióval létrehozott modell 


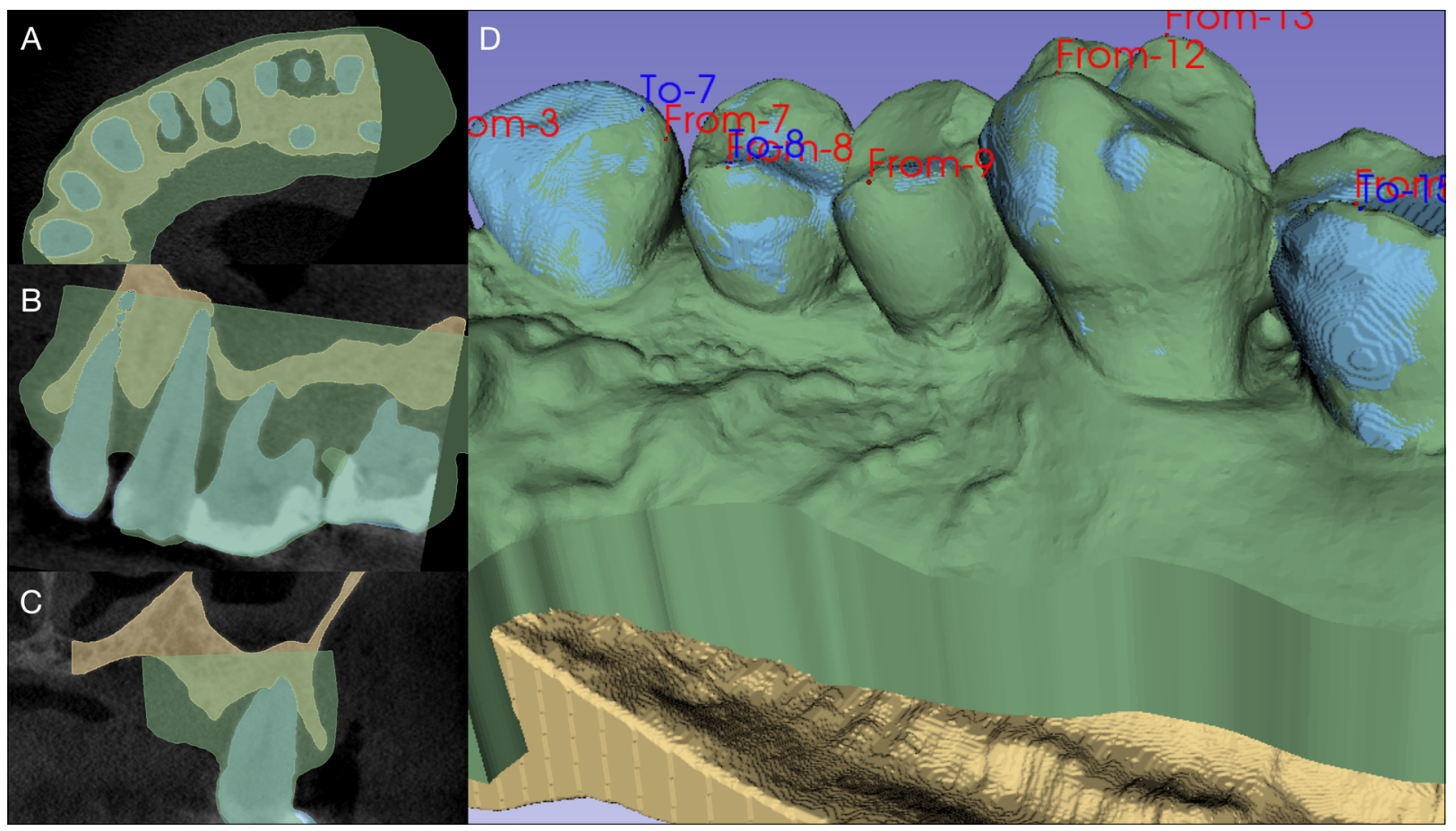

3. kép: 3D CBCT modell és intraorális szkenn illesztése:

A: Lágyrész szkenn illesztése 2D-ban (axiális) B: Lágyrész szkenn illesztése 2D-ban (axiális)

$C$ : Lágyrész szkenn illesztése 2D-ban (axiális) $D$ : Identikus pontok kijelölése

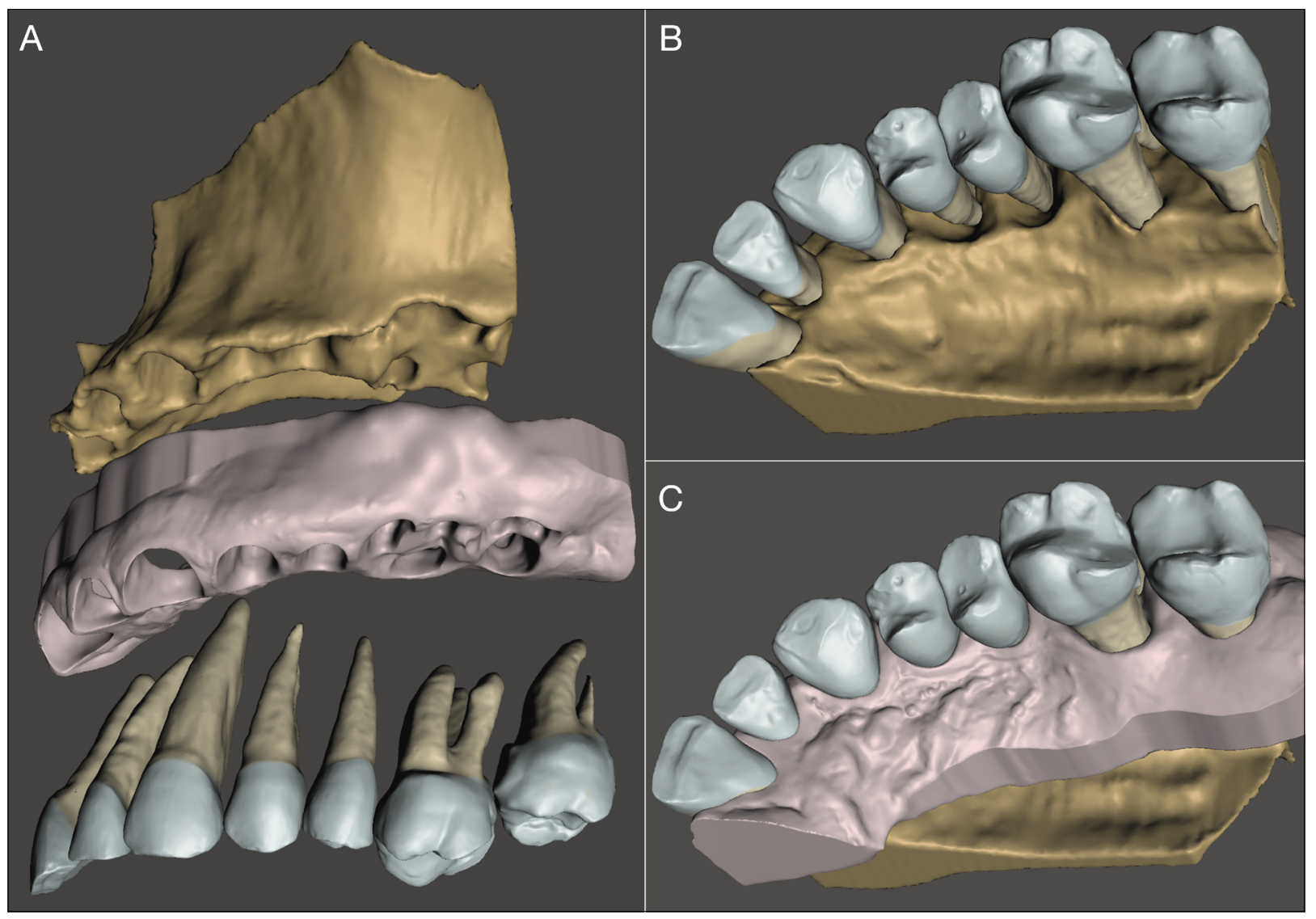

4. kép: CAD modellezéssel előállított realisztikus hibrid modell:

A: Hibrid modell kompozíciója (Fogak, alveoláris csont, lágyrészek)

$B$ : Keményszöveti modell a defektus 3D-s morfológiájának leképezésére

C: Hibrid modell a valós klinikai szituáció digitális szimulációja 


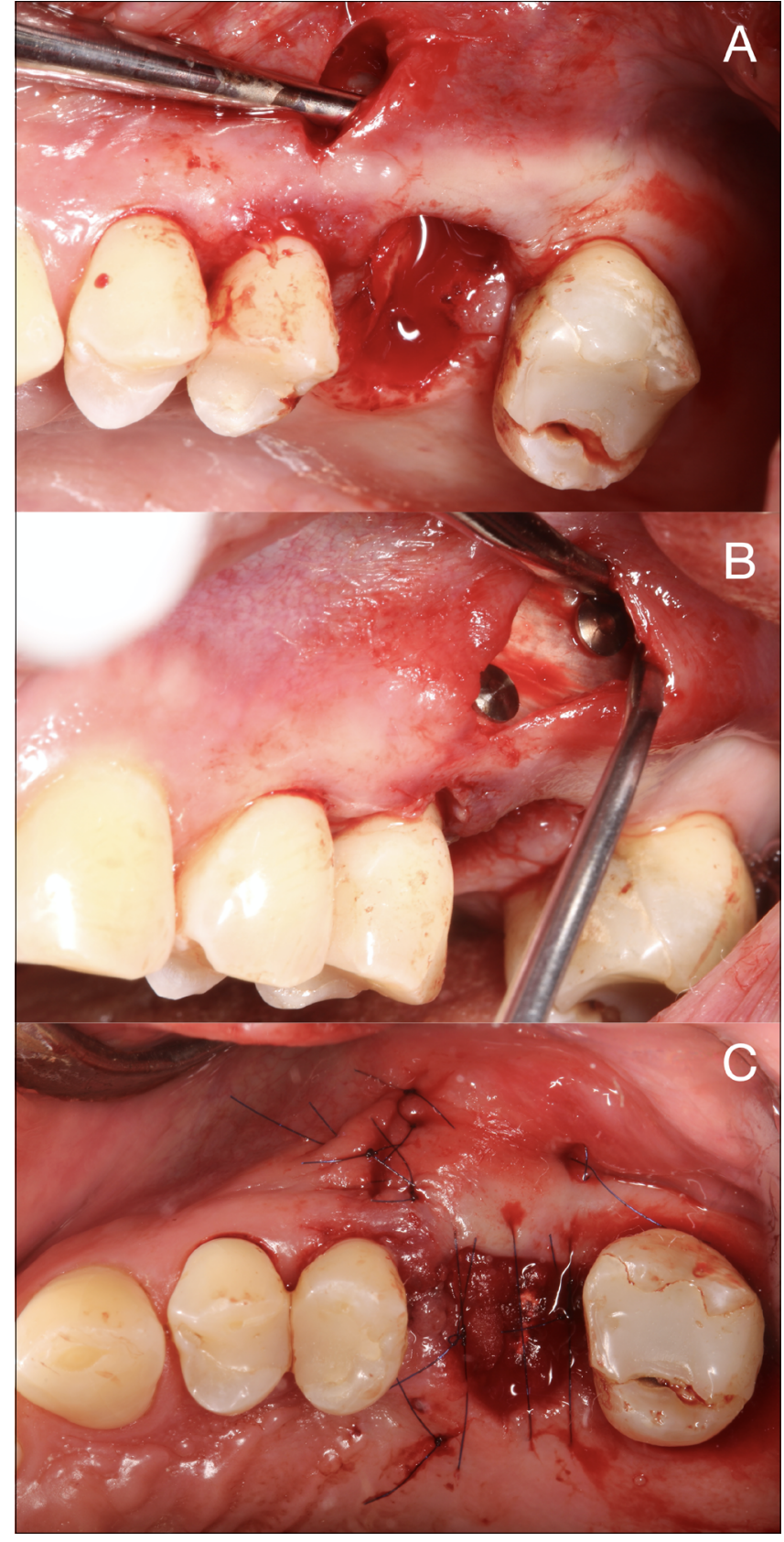

5. kép: Alveolus prezervációs beavatkozás: $A$ : Vertikális segédmetszésből kétrétegű tunnel képzése $B$ : Hosszú távon felszívódó membrán rögzítése a csont felszínen C: Sebzárás

\section{Második beavatkozás - Regeneratív célzatú parodontális sebészeti beavatkozás}

Alveolus prezervációs beavatkozás után egy hónappal a 24-es, 25-ös fogak körül kialakult horizonto-vertikális, cirkumdentális defektus regeneratív célzatú kezelését végeztük (6. kép). Helyi érzéstelenítésben paramarginálisan vezetett metszésből egyoldali palatinális teljesvastag lebenyt preparáltunk [20, 26]. Bukkálisan az interdentális térközök vonalában „pinhole” [2], metszéseket ejtettünk a fogak midbukkális felszíneinek elérése céljából. Így a marginális gingiva minimális mobilizációja mel- lett végeztük a defektus tisztítását kézi és gépi eszközökkel. A 3D-s virtuális modell alkalmazása a csökkent direkt vizuális kontroll mellett is könnyebb intraoperatív tájékozódást tett lehetővé. A defektus tisztítását követően irányított szövetregenerációs eljárást (guided tissue regeneration: GTR) alkalmaztunk felszívódó porcin eredetű kollagén membrán [25] (Bio-Guide ${ }^{\circledR}$, Geistlich AG, Wolhusen, Svájc) és kollagén mátrixba ágyazott bovin eredetú xenograft kombinációjával (Bio-Oss Collagen ${ }^{\circledR}$, Geistlich AG, Wolhusen, Svájc). A sebszéleket horizontális matracöltésekkel egyesítettük. Varratszedésre a mútét után 14 nappal került sor.

\section{Vizsgálati paraméterek}

A vizsgálat során célunk a bekövetkezett változások volumetrikus és lineáris kiértékelése. Térfogati változások vizsgálatához a preoperatív és postoperatív CBCT felvételek térbeli illesztését voxelek intenzitása közötti hasonlóságok alapján végeztük (3D Slicer, Elastix ${ }^{\circledR}$ ) [16]. A preoperatív és postoperatív poligon modellek szubsztrakciójával (3D Slicer, Segment editor, Logical operators) megkapjuk a két modell közötti különbséget, melynek térfogatát a "Segement statistics" modul segítségével határoztuk meg (7. kép).

A 24-es, 25-ös fogak körüli parodontális defektus telődésének mértékét digitális lineáris mérésekkel és klinikai paraméterek változásának vizsgálatával értékeltük ki. A fogak meziális (mes.), disztális (dist.), bukkális (bukk.) és palatinális (palat.) felszínén a kiindulási és 9 hónapos $\mathrm{CBCT}$ felvétel alapján rekonstruált modelleken a következő paramétereket mértük: (i) zománccement határ (cemento-enamel junction: $\mathrm{CEJ}$ ) és a defektus bázisa (base of the defect: BD) közötti távolság: $C E J-B D$, (ii) zománc-cement határ és a kresztális csontszél (bone crest: $\mathrm{BC}$ ) közötti távolság: $C E J-B C$, (iii) a kresztális csontszél és a defektus bázisa közötti távolság (intraosszer komponens vertikális dimenziója): INTRA, (iv) fogfelszín és a kresztális csontszél közötti távolság (intraosszer komponens horizontális dimenziója): WIDTH, (v) zománc-cement határ és a marginális ínyszél közötti távolság (virtuális ínyrecesszió): VREC, (vi) marginális ínyszél és a defektus bázisa közötti távolság (virtuális bone sounding): VBS [5, 17] (8. kép).

Digitális mérések mellett vizsgáltuk a klinikai paraméterek változását: (i) szondázási tasakmélység (PPD: probing pocket depth), (ii) ínyrecesszió (REC), (iii) klinikai tapadási nívó (CAL: clinical attachement level), (iv) szájhigiéne foka (FMPS: full mouth plaque score) és (v) reziduális gyulladás szintje (FMBS: full mouth bleeding score).

Pre- és postoperatív CEJ-BD értékek összehasonlításával meghatározható az adott fogfelszínen a defektus intraosszer komponensének keményszöveti telődése. Pre- és postoperatív CEJ-BC értékek összehasonlításával meghatározható az adott fogfelszínen bekövetkezett kresztális csontrezorpció. Az intraosszer defektus kiindulási mélysége és a CEJ-BD értékek közötti kü- 


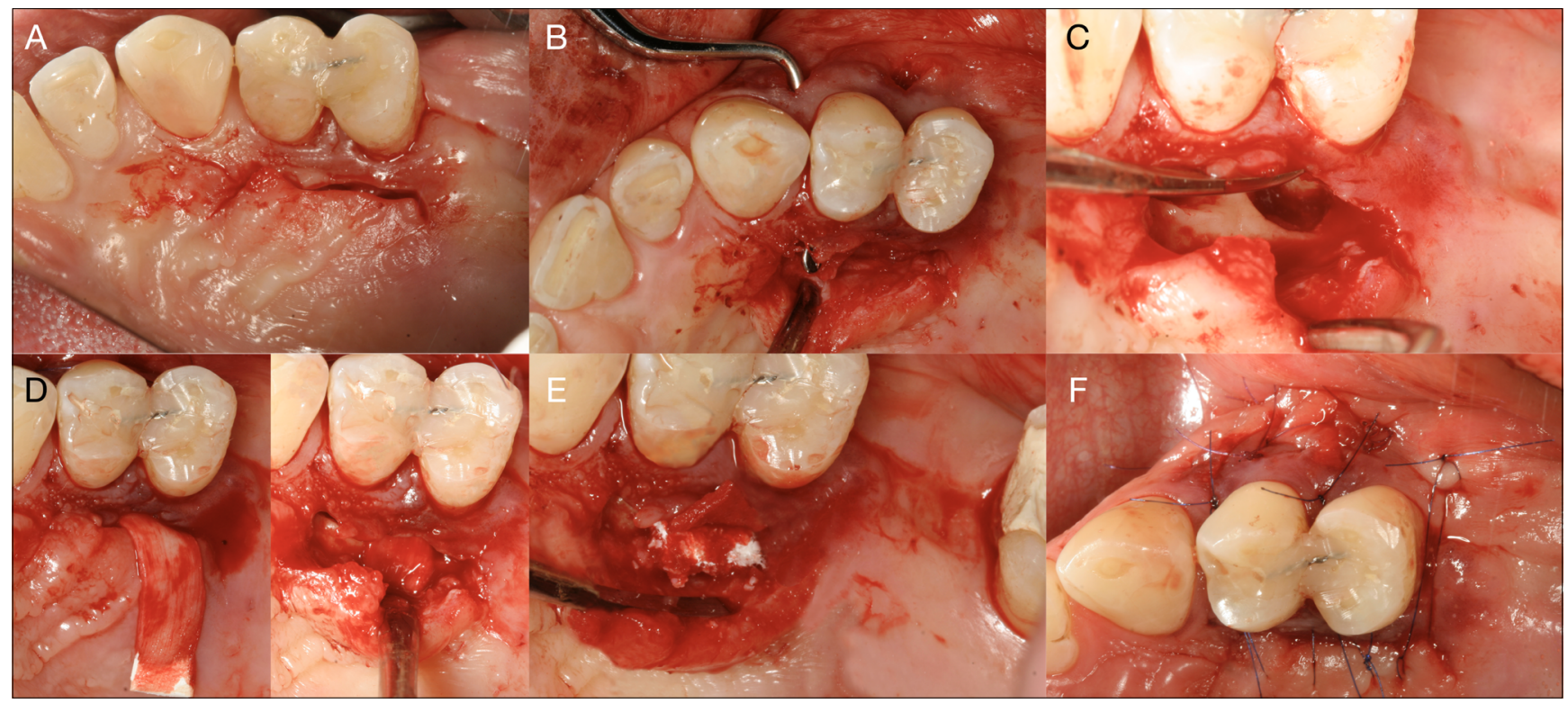

6. kép: Premoláris fogak körül kialakult defektus regeneratív célzatú ellátása:

$A$ : Palatinális paramarginálisan vezetett metszés $B$ : Bukkális pinhole metszésekből interdentális papilla alápreparálása

$C$ : Defektusmorfológia $D$ : Kollagén membrán befúzése interdentálisan $E$ : Kollagénbe ágyazott xenograft behelyezése a defektusba $F$ : Sebzárás
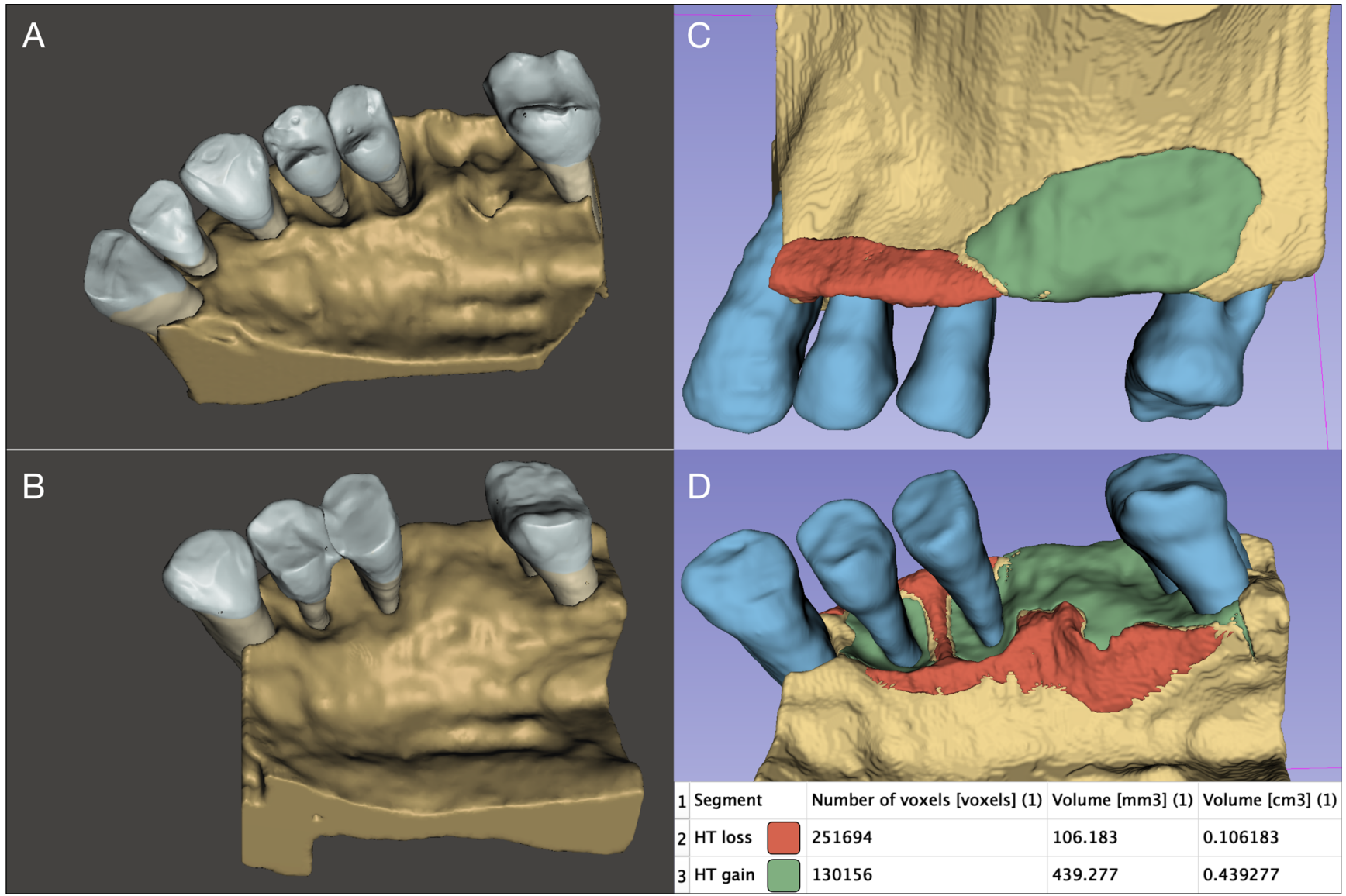

7. kép: Mútéti beavatkozások volumetrikus kiértékelése:

$A$ : Kiindulási defektusmorfológia $B$ : 9 hónapos kontroll állapot

$C$ : Bukkális keményszöveti nyereség és veszteség $D$ : alatinális keményszöveti nyereség és veszteség 


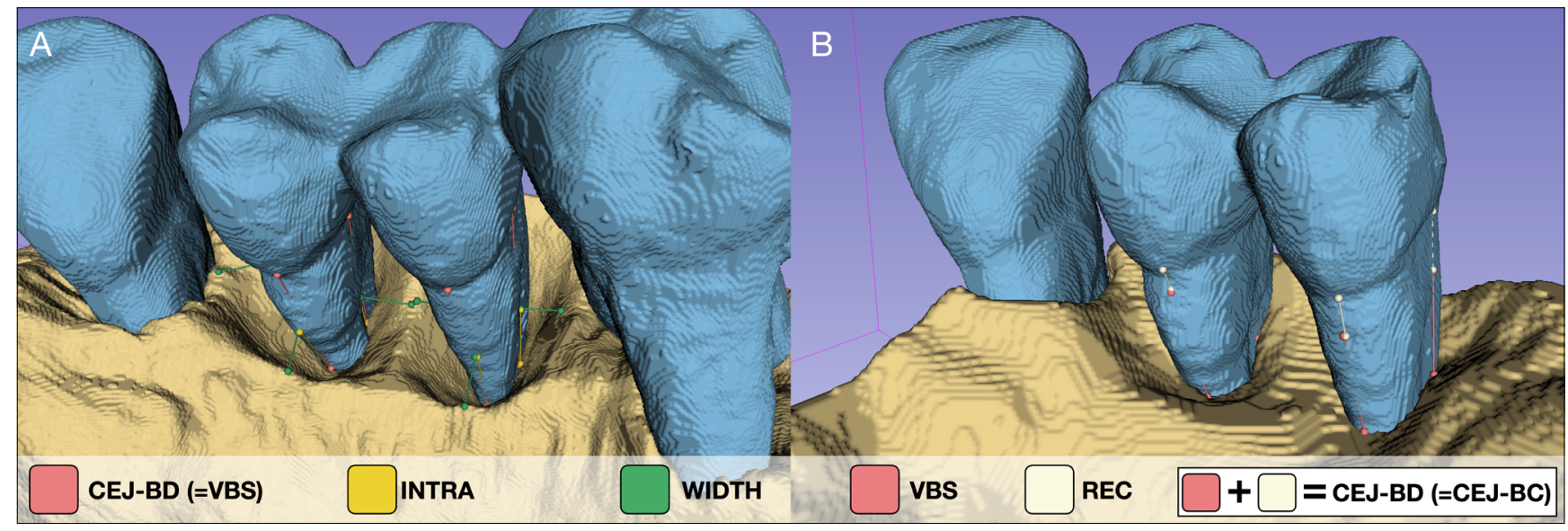

8. kép: Digitális lineáris mérések a premoláris fogak körül négy ponton: $A$ : Preoperatív mérések $B$ : Postoperatív mérések

lönbség aránya alapján meghatározható a defektus telődésének mértéke.

\section{Eredmények}

A lépcsőzetes mútéti kezelés eredményeként az érintett területen összesen $0,44 \mathrm{~cm}^{3}$ keményszöveti többlet keletkezett. Ezzel együtt megfigyelhető kismértékủ marginális csontrezorpció a palatinális és bukkális csontszéleken melynek mértéke összesen $0,11 \mathrm{~cm}^{3}$ (9. kép).

Lineáris méréseket a 24-es és 25-ös fog 4 felszínén végeztünk, a második beavatkozás kiértékelése céljából. A 24-es fog körül a CEJ-BD értékek 2,08 mmrel (mes.), 1,17 mm-rel (palat.), 1,35 mm (dist.) és 0,31 mm-rel (bukk.) csökkent. A fog körül a defektus intraosszer komponense átlagosan $45,5 \pm 38,55 \%$-os telődést mutatott. Míg a CEJ-BC értékek 0,39 mm-rel (mes.), 3,06 mm-rel (palat.), 0,57 mm-rel (dist.), 1,18 mmrel (bukk.) növekedett. 25-ös fog körül a CEJ-BD érték 3,08 mm-rel (mes.), 2,18 mm-rel (palat.), 3,18 mmrel (dist.), 0,31 mm-rel (bukk.) csökkent. A fog körüli cirkumdentális defektus $62,25 \pm 38,65 \%$-os átlag keményszöveti telődést mutatott. CEJ-BC értékek $0,7 \mathrm{~mm}$ rel (mes.), 1,57 mm-rel (palat.), 2,59 mm-rel (bukk.) növekedett, míg a fog disztális felszínén nem változott, $100 \%$-os telődést eredményezve a fog disztális felszínén. $A$ két fog körül átlagosan $1,22 \pm 0,87 \mathrm{~mm}$ postoperatív ínyrecesszió alakult ki, a defektus szupraosszer komponensének csökkenését eredményezve (10. kép). A kiindulási átlagos 7,00 $\pm 2,04 \mathrm{~mm}$-es tasakmélység 9 hónapos gyógyulási periódust követően $3,30 \pm 0,88$ ra csökkent. A lineáris mérési eredmények részletes összefoglalása az 1. táblázatban látható (1. táblázat). A vizsgált klinikai paraméterek változását a 2. táblázatban foglaltuk össze (2. táblázat).

\section{Megbeszélés}

Jelen esetismertetésben egy komplex, több fogra kiterjedő parodontális defektus kétlépcsős, regeneratív-rekonstruktív sebészi ellátását mutattuk be. A defektus valódi térbeli morfológiájának feltérképezését, a mútétek tervezését és a postoperatív kiértékelést valósághü, a fogakat, az alveoláris csontot és lágyrészeket is egyaránt tartalmazó virtuális modell alapján végeztük. A modelleket a csoportunk által már korábban leírt félautomata szegmentációs módszerrel hoztuk létre.

CBCT alapján rekonstruált 3D-s modelleket már korábban is alkalmaztak parodontális diagnosztika céljából. Ezen közlemények többségében automata határérték alapú szegmentációs algoritmust alkalmaznak [13, $18,23]$. A félautomatikus szegmentációs módszer előnye, hogy a különböző anatómiai struktúrák jól elkülönülnek egymástól, így feltérképezhető a defektusok valós térbeli morfológiája. 2020-ban megjelent közleményben Palkovics és mtsai összehasonlították a hagyományos parodontális diagnosztikus eszközök (klinikai szondázás és intraorális röntgenfelvétel) és a CBCT alapján rekonstruált háromdimenziós modellek diagnosztikus pontosságát. Hagyományos diagnosztikus eszközökkel csak egy esetben lehetett megállapítani a parodontális defektus pontos morfológiáját, míg a virtuális 3D-s modell segítségével minden esetben pontosan meg tudták állapítani a defektusok morfológiáját [21]. A félautomatikus szegmentációs módszerrel előállított modell minőségét nagyban befolyásolja a CBCT felvétel minősége és a voxelméret. További hátránya az ismertetett módszernek, hogy a félautomatikus szegmentáció időigényes folyamat.

Jelen esetismertetésben a fogak és az alveoláris csont modellezése mellett, intraorális szkennerrel vett digitális minta segítségével a lágyrészeket is tartalmazó hibrid modellt hoztunk létre, mely alapján a mútétet virtuá- 


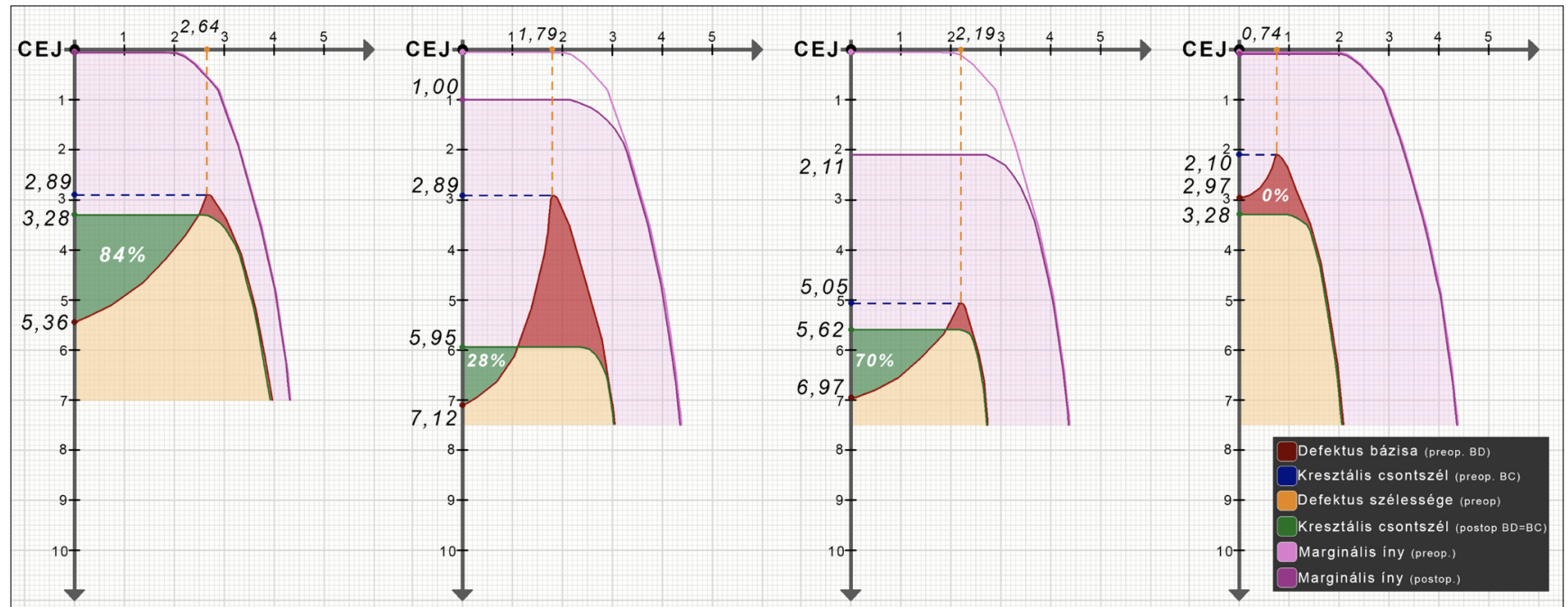

\section{Mesiális felszín Palatinális felszín Distális felszín Bukkális felszín}

9. kép: 24-es fog körüli defektus gyógyulási mehanizmusa
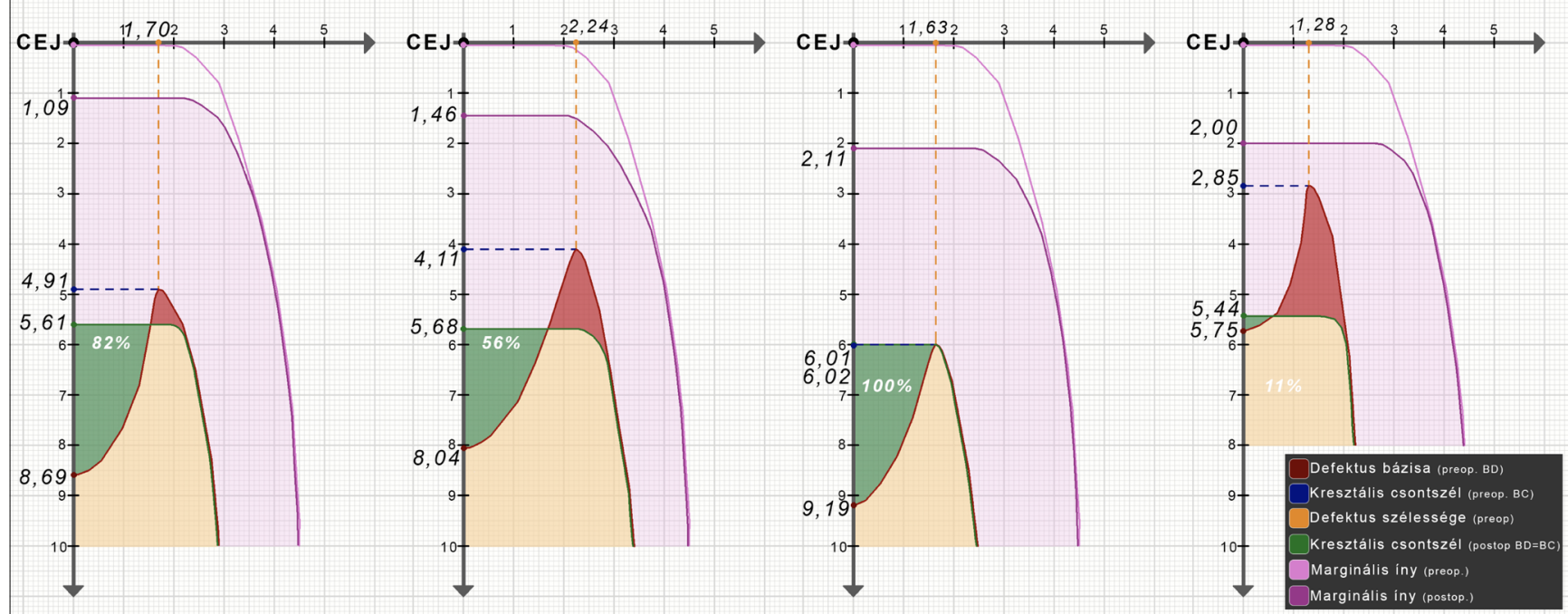

Mesiális felszín

Palatinális felszín Distális felszín

Bukkális felszín

10. kép: 25-ös fog körüli defektus gyógyulási mehanizmusa

lisan szimuláltuk a beavatkozás előtt. A 3D-s leképezés lehetővé tette a defektus nagy kiterjedése és komplex morfológiája ellenére is a minimálinvazív sebészeti ellátást, melyet a 26-os fog eltávolításával egybekötött alveolus prezerváció során az XSD technikának megfelelően végeztünk [19]. A minimális lebenyeleváció jobb postoperatív vérrög stabilitást eredményez, így xenograft alkalmazása nélkül érhető el az alveolus keményszöveti telődése. A premolárisokat érintő horizonto-vertikális defektus kezelését a korábban leírt „non-incised papillae surgical approach (NIPSA)” technikához hasonlóan az interdentális papillák átvágása nélkül, a marginális gingiva minimális mobilizációja mellett végeztük [20].

A kiindulási és 9 hónapos CBCT felvételek szubtrakciójával a bekövetkezett keményszöveti volumetrikus és morfológiai változásokat is kiértékeltük. Hasonló módszert alkalmaztak már extrakciót követő morfológiai és volumetrikus változások elemzésére [3], valamint gerincaugmentációs beavatkozások eredményének kiértékelésére [9], azonban parodontális defektusok gyógyulását mindeddig nem vizsgálták ilyen módszerrel. A kumulatív keményszöveti nyereség összesen $0,44 \mathrm{~cm}^{3}$ volt. A 26-os fog helyén történt belső telődés és buk- 
Lineáris mérési eredmények

\begin{tabular}{|c|c|c|c|c|c|c|c|c|c|c|c|c|}
\hline & \multicolumn{12}{|c|}{ 24-es fog } \\
\hline & \multicolumn{3}{|c|}{ Meziális } & \multicolumn{3}{|c|}{ Palatinális } & \multicolumn{3}{|c|}{ Disztális } & \multicolumn{3}{|c|}{ Bukkális } \\
\hline & Preop. & Postop. & Változás & Preop. & Postop. & Változás & Preop. & Postop. & Változás & Preop. & Postop. & Változás \\
\hline $\begin{array}{l}\text { Virtuális } \\
\text { Bone } \\
\text { Sounding }\end{array}$ & 5,36 & 3,28 & 2,08 & 7,12 & 4,95 & 2,17 & 6,97 & 3,51 & 3,46 & 2,97 & 3,28 & 0,31 \\
\hline CEJ-BD & 5,36 & 3,28 & $-2,08$ & 7,12 & 5,95 & $-1,17$ & 6,97 & 5,62 & $-1,35$ & 2,97 & 3,28 & $-0,31$ \\
\hline CEJ-BC & 2,89 & 3,28 & 0,39 & 2,89 & 5,95 & 3,06 & 5,05 & 5,62 & 0,57 & 2,1 & 3,28 & 1,18 \\
\hline INTRA & 2,47 & - & - & 4,23 & - & - & 1,92 & - & - & 0,87 & - & - \\
\hline \multirow[t]{4}{*}{ WIDTH } & 2,64 & - & - & 1,79 & - & - & 2,19 & - & - & 0,74 & - & - \\
\hline & \multicolumn{12}{|c|}{ 25-ös fog } \\
\hline & \multicolumn{3}{|c|}{ Meziális } & \multicolumn{3}{|c|}{ Palatinális } & \multicolumn{3}{|c|}{ Disztális } & \multicolumn{3}{|c|}{ Bukkális } \\
\hline & Preop. & Postop. & Változás & Preop. & Postop. & Változás & Preop. & Postop. & Változás & Preop. & Postop. & Változás \\
\hline $\begin{array}{l}\text { Virtuális } \\
\text { Bone } \\
\text { Sounding }\end{array}$ & 8,69 & 4,52 & 4,17 & 8,04 & 4,22 & 3,82 & 9,19 & 3,9 & 5,29 & 5,75 & 3,39 & 2,36 \\
\hline CEJ-BD & 8,69 & 5,61 & $-3,08$ & 8,04 & 5,68 & $-2,18$ & 9,19 & 6,01 & $-3,18$ & 5,75 & 5,44 & $-0,31$ \\
\hline CEJ-BC & 4,91 & 5,61 & 0,7 & 4,11 & 5,68 & 1,57 & 6,02 & 6,01 & $-0,01$ & 2,85 & 5,44 & 2,59 \\
\hline INTRA & 3,78 & - & - & 3,93 & - & - & 3,17 & - & - & 2,9 & - & - \\
\hline WIDTH & 1,7 & - & - & 2,24 & - & - & 1,63 & - & - & 1,28 & - & - \\
\hline
\end{tabular}

Klinikai paraméterek

\begin{tabular}{|c|c|c|c|c|c|c|c|c|c|c|c|c|}
\hline & \multicolumn{12}{|c|}{ 24-es fog } \\
\hline & \multicolumn{3}{|c|}{ Meziális } & \multicolumn{3}{|c|}{ Palatinális } & \multicolumn{3}{|c|}{ Disztális } & \multicolumn{3}{|c|}{ Bukkális } \\
\hline & Preop. & Postop. & Változás & Preop. & Postop. & Változás & Preop. & Postop. & Változás & Preop. & Postop. & Változás \\
\hline$P P D$ & 10 & 4 & 6 & 8 & 3 & 5 & 7 & 4 & 3 & 2 & 2 & 0 \\
\hline$G R$ & 0 & 0 & 0 & 0 & 1 & 1 & 0 & 2,11 & 2,11 & 0 & 0 & 0 \\
\hline \multirow[t]{4}{*}{$C A L$} & 10 & 4 & 6 & 8 & 4 & 4 & 7 & 6,11 & 1,11 & 2 & 2 & 0 \\
\hline & \multicolumn{12}{|c|}{ 25-ös fog } \\
\hline & \multicolumn{3}{|c|}{ Meziális } & \multicolumn{3}{|c|}{ Palatinális } & \multicolumn{3}{|c|}{ Disztális } & \multicolumn{3}{|c|}{ Bukkális } \\
\hline & Preop. & Postop. & Változás & Preop. & Postop. & Változás & Preop. & Postop. & Változás & Preop. & Postop. & Változás \\
\hline$P P D$ & 8 & 4 & 4 & 6 & 3 & 3 & 9 & 4 & 5 & 6 & 3 & 3 \\
\hline$G R$ & 0 & 1,09 & 1,09 & 0 & 1,46 & 1,46 & 0 & 2,11 & 2,11 & 0 & 2 & 2 \\
\hline$C A L$ & 8 & 5,09 & 3,09 & 6 & 4,46 & 1,54 & 9 & 6,11 & 3,11 & 6 & 5 & 1 \\
\hline
\end{tabular}

kális csontfalvastagodás mellett minimális palatinális csontrezorpció látható. A 24-es és 25-ös fogak körül kialakult cirkumdentális, horizonto-vertikális defektus átlagosan 53,88 \pm 36,84\%-os keményszöveti telődést mutatott, a kresztális csontszél kismértékű lebomlása mellett. Átlagosan 1,22 \pm 0,87 ínyrecesszió alkult ki, mely a defektus horizontális komponensének csökkenését eredményezte. A legnagyobb mértékű javulás a 25-ös fog disztális felszínén következett be, ahol az intraosszer komponens 100\%-os telődése volt megfigyelhető. Korábbi klinikai tapasztalatunk alapján a regeneratív célzatú tasakmútét mellett az alveolus prezerváció indirekt hatása is szerepet játszott a defektus kedvező gyógyulásában. Megfigyelhető a 26-os fog alveolusa körüli palatinális csontszél, valamint a 24-es és 25-ös fogak körüli bukkális és palatinális kresztális csontszél rezorpciója, melynek mértéke összesen $0,11 \mathrm{~cm}^{3}$. A kialakult csontrezorpció okának pontos megismeréséhez további vizsgálatok elvégzése szükséges.

Konklúzióként megállapítható, hogy valósághű hibrid modellek segítségével nagy alapossággal tervezhetők a regeneratív-rekonstruktív sebészeti beavatkozások lépései, valamint pre- és postoperatív CBCT felvételek szubtrakciójával megismerhettük a defektus gyógyulásának mechanizmusait. Volumetrikus és lineáris mérésekkel vizsgáltuk annak mértékét, melyet korábban egy közlemény sem írt le. Jelen módszer nagyon ígéretes mind defektusok diagnosztikájában, a mútétek tervezésében, valamint az eredmények postoperatív kiértékelésében. Azonban a metódus pontosabb kiértékelé- 
se céljából szükséges további prospektív vizsgálatok elvégzése.

Köszönetnyilvánítás: Szerzők szeretnének köszönetet mondani dr. Nagy Katalin Professzor Asszonynak és dr. Molnár Bálint Docens Úrnak a nélkülözhetetlen szakmai támogatásukért

\section{Irodalom}

1. Azuma H, Kono T, Morita H, Tsumorı N, Mikı H, Shiomı K et al: Single Flap Periodontal Surgery Induces Early Fibrous Tissue Generation by Wound Stabilization.

Journal of Hard Tissue Biology 2017; 26 (2): 119-126 https://doi.org/10.2485/jhtb.26.119

2. CHAO JC: A novel approach to root coverage: the pinhole surgical technique. Int J Periodontics Restorative Dent 2012 Oct; 32 (5): 521-531. PMID: 22754900.

3. Chappuis V, Engel O, Reyes M, Shahim K, Nolte LP, Buser D: Ridge alterations post-extraction in the esthetic zone: a 3D analysis with CBCT. J Dent Res 2013 Dec; 92 (12 Suppl): 195S-201S. Epub 2013 Oct 24. PMID: 24158340; PMCID: PMC3860068. https://doi.org/10.1177/0022034513506713

4. Chiu HC, Shen EC, Lin SJ, Susin C, Wikesjö UM, Fu E: Periodontal repair in dogs: space-provision supports alveolar bone and cementum formation. J Clin Periodontol $2013 \mathrm{Apr}$; 40 (4): 358-363. Epub 2013 Feb 15. PMID: 23410055. https://doi.org/10.1111/jcpe.12071

5. Cortellini P, Pini Prato G, Tonetti MS: Periodontal regeneration of human infrabony defects. II. Re-entry procedures and bone measures. J Periodontol 1993 Apr; 64 (4): 261-268. PMID: 8483088. https://doi.org/10.1902/jop.1993.64.4.261

6. Cortellini $P$, Tonetti MS: A minimally invasive surgical technique with an enamel matrix derivative in the regenerative treatment of intra-bony defects: a novel approach to limit morbidity. J Clin Periodontol 2007 Jan; 34 (1): 87-93. PMID: 17243998. https://doi.org/10.1111/j.1600-051X.2006.01020.x

7. CORTELLINI $P$, TONETTI MS: Improved wound stability with a modified minimally invasive surgical technique in the regenerative treatment of isolated interdental intrabony defects. J Clin Periodontol 2009 Feb; 36 (2): 157-163. PMID: 19207892. https://doi.org/10.1111/j.1600-051X.2008.01352.x

8. De Faria Vasconcelos K, Evangelista KM, Rodrigues CD, Estrela C, De Sousa to, Silva MA: Detection of periodontal bone loss using cone beam CT and intraoral radiography.

Dentomaxillofac Radiol 2012 Jan; 41 (1): 64-69. PMID: 22184627; PMCID: PMC3520280. https://doi.org/10.1259/dmfr/13676777

9. Economopoulos TL, Asvestas PA, Matsopoulos GK, Molnár B, WINDISCH P: Volumetric difference evaluation of registered threedimensional pre-operative and post-operative CT dental data. Dentomaxillofac Radiol 2012 May; 41 (4): 328-339. Epub 2012 Jan 12. PMID: 22241879; PMCID: PMC3728999. https://doi.org/10.1259/dmfr/94040044

10. Fedorov A, Beichel R, Kalpathy-Cramer J, Finet J, Fillion-Robin JC, Pujol S, et al: 3D Slicer as an image computing platform for the Quantitative Imaging Network. Magn Reson Imaging 2012 Nov; 30 (9): 1323-1341. Epub 2012 Jul 6. PMID: 22770690; PMCID: PMC3466397. https://doi.org/10.1016/j.mri.2012.05.001

11. Gera I: A fogágybetegség és a peri-implant betegségek új klasszifikációja: Az American Academy of Periodontology (AAP) és a European Federation of Periodontology (EFP) World Workshop on the Classification of Periodontal and Periimplant Diseases and Conditions (2017) konszenzus riportja 2. rész: A parodontitis klasszifikációja.

Fogorvosi Szemle 2018 Dec; 111 (4): 114-122.

12. Grimard BA, Hoidal MJ, Mills MP, Mellonig JT, Nummikoski PV, MeALEY BL: Comparison of clinical, periapical radiograph, and cone-beam volume tomography measurement techniques for assessing bone level changes following regenerative periodontal therapy. J Periodontol 2009 Jan; 80 (1): 48-55. PMID: 19228089. https://doi.org/10.1902/jop.2009.080289

13. Güth JF, Kauling AEC, Schweiger J, Kühnisch J, Stimmelmayr M: Virtual Simulation of Periodontal Surgery Including Presurgical CAD/CAM Fabrication of Tooth-Colored Removable Splints on the Basis of CBCT Data: A Case Report. Int J Periodontics Restorative Dent 2017 Nov/Dec; 37 (6): e310-e320. PMID: 29023614. https://doi.org/10.11607/prd.2769

14. HARREL SK: A minimally invasive surgical approach for periodontal regeneration: surgical technique and observations. $J$ Periodontol 1999 Dec; 70 (12): 1547-1557. PMID: 10632530. https://doi.org/10.1902/jop.1999.70.12.1547

15. Jacobs R, Salmon B, Codari M, Hassan B, Bornstein MM: Cone beam computed tomography in implant dentistry: recommendations for clinical use. BMC Oral Health 2018 May 15; 18 (1): 88. PMID: 29764458; PMCID: PMC5952365. https://doi.org/10.1186/s12903-018-0523-5

16. Klein S, Staring M, Murphy K, Viergever MA, PlUim JP: Elastix: a toolbox for intensity-based medical image registration. IEEE Trans Med Imaging 2010 Jan; 29 (1): 196-205. Epub 2009 Nov 17. PMID: 19923044. https://doi.org/10.1109/TMI.2009.2035616

17. LI F, JIA PY, OUYANG XY: Comparison of Measurements on Cone Beam Computed Tomography for Periodontal Intrabony Defect with Intra-surgical Measurements. Chin J Dent Res 2015 Sep; 18 (3): 171-176. PMID: 26485509.

18. Mohan R, Mark R, Sing I, Jain A: Diagnostic Accuracy of CBCT for Aggressive Periodontitis. J Clin Imaging Sci. 2014 May 27; 4 (Suppl 2): 2. PMID: 25191628; PMCID: PMC4141417. https://doi.org/10.4103/2156-7514.133258

19. Molnár B, Deutsch T, Marton R, Orbán K, Martin A, Windisch P: Demonstration of Radiographic Bone Fill in Postextraction Sockets Using a Novel Implant-Site Development Technique: A Retrospective Comparative Case Series. Int J Periodontics Restorative Dent 2019; 39 (6): 845-852. https://doi.org/10.11607/prd.4106

20. Moreno Rodríguez JA, Ortiz Ruiz aJ, Caffesse RG: Periodontal reconstructive surgery of deep intraosseous defects using an apical approach. Non-incised papillae surgical approach (NIPSA): A retrospective cohort study. J Periodontol 2019 May; 90 (5): 454-464. Epub 2018 Nov 28. PMID: 30421495. https://doi.org/10.1002/JPER.18-0405

21. Palkovics D, Mangano FG, Nagy K, Windisch $P$ : Digital three-dimensional visualization of intrabony periodontal defects for regenerative surgical treatment planning. BMC Oral Health 2020 Dec 1; 20 (1): 351. PMID: 33261592; PMCID: PMC7709443. https://doi.org/10.1186/s12903-020-01342-w

22. Papapanou PN, Sanz M, Buduneli N, Dietrich T, Feres M, Fine DH, et al: Periodontitis: Consensus report of workgroup 2 of the 2017 World Workshop on the Classification of Periodontal and Peri-Implant Diseases and Conditions. J Periodontol 2018 Jun; 89 Suppl 1: S173-S182. PMID: 29926951. https://doi.org/10.1002/JPER.17-0721

23. Scarfe WC, Azevedo B, Pinheiro LR, Priaminiarti M, Sales MaO: The emerging role of maxillofacial radiology in the diagnosis and management of patients with complex periodontitis. Periodontol 20002017 Jun; 74 (1): 116-139. PMID: 28429477. https://doi.org/10.1111/prd.12193

24. Schincaglia GP, Hebert E, Farina R, Simonelli A, Trombelli L: Single versus double flap approach in periodontal regenerative 
treatment. J Clin Periodontol 2015 Jun; 42 (6): 557-566. Epub 2015 May 29. PMID: 25924545. https://doi.org/10.1111/jcpe.12409

25. Sculean A, Chiantella GC, Windisch P, Arweiler NB, Brecx M, GerA I: Healing of intra-bony defects following treatment with a composite bovine-derived xenograft (Bio-Oss Collagen) in combination with a collagen membrane (Bio-Gide PERIO). J Clin Periodontol 2005 Jul; 32 (7): 720-724. PMID: 15966877. https://doi.org/10.1111/j.1600-051X.2005.00758.x

26. Trombelli L, Farina R, Franceschetti G, Calura G: Single-flap approach with buccal access in periodontal reconstructive procedures. J Periodontol 2009 Feb; 80 (2): 353-360.
PMID: 19186978

https://doi.org/10.1902/jop.2009.080420

27 VANDENBERGhe B, JACOBS R, YANG J: Diagnostic validity (or acuity) of 2D CCD versus 3D CBCT-images for assessing periodontal breakdown. Oral Surg Oral Med Oral Pathol Oral Radiol Endod 2007 Sep; 104 (3): 395-401. Epub 2007 Jul 5. PMID: 17613257. https://doi.org/10.1016/j.tripleo.2007.03.012

28. Walter C, Kaner D, Berndt DC, Weiger R, Zitzmann NU: Three-dimensional imaging as a pre-operative tool in decision making for furcation surgery. J Clin Periodontol 2009 Mar; 36 (3): 250-257. PMID: 19236537. https://doi.org/10.1111/j.1600-051X.2008.01367.x

\section{Solyom E, Palkovics D, Pinter Cs, Francesco GM, Windisch P \\ Virtual planning and volumetric evaluation in the regenerative-reconstructive surgical treatment of a complex periodontal defect}

Case presentation

Aim: Our aim was to present the regenerative-reconstructive surgical treatment of a complex periodontal defect. Surgical treatment planning was carried out on realistic virtual hybrid models, containing all relevant anatomical structures (teeth, alveolar bone and gingiva). Additional aim was to evaluate the outcome of the surgical treatment, by the superimposition of pre- and postoperative cone-beam computed tomography (CBCT) scans.

Materials and methods: Utilizing a semi-automatic segmentation method, the 3D model of teeth and alveolar bone was generated from the CBCT scan using the open source radiographic image processing software, 3D Slicer. Spatial registration of the hard tissue model acquired from the CBCT scan and the digital model acquired with an intraoral scanner was performed based on anatomical landmarks. First step of the planned stepwise surgical treatment was the extraction and simultaneous alveolar ridge preservation of tooth 26 . Surgery was carried out according to the extraction site development (XSD) technique. Second step was the regenerative treatment of the horizonto-vertical periodontal defect involving tooth 24 and 25. Superimposition of the pre- and postoperative CBCT scans allowed to validate the volumetric and linear changes.

Results: In the surgical area the cumulative hard tissue gain was $0.44 \mathrm{~cm}^{3}$. Crestal bone resorption of $0.11 \mathrm{~cm}^{3}$ occurred at the palatal and buccal aspects. Linear measurements were performed to evaluate the hard tissue fill of the periodontal defect around tooth 24 and 26 . On average the intrabony component showed a $53.88 \pm 36.84 \%$ of hard tissue fill, with minor crestal bone resorption. On average a $1.22 \pm 0.87 \mathrm{~mm}$ of gingival recession occurred around the teeth. Conclusion: It can be concluded that hybrid models acquired with the aforementioned technique allowed detailed planning of the surgical procedures. With the application of the postoperative volumetric and linear evaluation, the healing dynamics of the complex defect could be demonstrated thoroughly.

Keywords: virtual surgical planning, regenerative-reconstructive periodontal surgery, alveolar ridge preservation, volumetric evaluation $\mathrm{CBCT}$, segmentation, 3D radiographic image reconstruction 